\title{
Do CENTRAL BANKS HAVE PRECAUTIONARY DEMANDS FOR EXPANSIONS AND FOR PRICE STABILITY? - THEORY AND EVIDENCE
}

\author{
AlEX CUKIERMAN \\ V. ANTON MUSCATELLI \\ CESIFO WORKING PAPER NO. 764 \\ CATEGORY 6: MONETARY POLICY AND INTERNATIONAL FINANCE \\ August 2002 \\ An electronic version of the paper may be downloaded \\ - from the SSRN website: www.SSRN.com \\ - from the CESifo website: www.CESifo.de
}




\title{
Do CENTRAL BANKS HAVE PRECAUTIONARY DEMANDS FOR EXPANSIONS AND FOR PRICE STABILITY? - THEORY AND EVIDENCE
}

\begin{abstract}
This paper analyses the impact of asymmetric preferences with respect to inflation and output by policymakers on interest-rate reaction functions and test for their existence. A modified New Keynesian framework which makes it possible to identify the dominant type of asymmetry is developed and related to the precautionary demand of policymakers for expansions and for low inflation. Using data for four G7 economies, the paper shows that, except for Germany, nonlinear and asymmetric behaviour is present. A main finding, for the US, is that after credibility-building and disinflation have been established, the monetary authority develops a greater precautionary demand for output expansions than for low inflation. This may generate a new type of inflation bias. Conversely, where, as is the case in the UK, credibility-building is still a concern for the authorities, managing the business cycle is dominated by concerns of the monetary authorities to keep inflation expectations low.
\end{abstract}

JEL Classification: E58, E61.

\author{
Alex Cukierman \\ Berglas School of Economics \\ Tel-Aviv University \\ Tel-Aviv, 69978 \\ Israel
}

\author{
V. Anton Muscatelli \\ Department of Economics \\ University of Glasgow \\ Adam Smith Building \\ Glasgow G12 8RT \\ United Kingdom \\ V.A.Muscatelli@socsci.gla.ac.uk
}

We benefitted from reactions of seminar participants at Tel-Aviv University, the Bank of England, the Bank of Israel, Stanford University, the Federal Reserve Bank of St-Louis, Leeds University, and Bari University. We are particularly grateful to Adrian Pagan and to Simon Price for comments. The usual disclaimer applies. 


\section{Introduction}

The 1990s have seen the emergence of an apparent consensus in monetary policymaking. This is exemplified by the fact that standard linear-quadratic models of central bank (CB) preferences dominate discussion of monetary policy rules ${ }^{1}$. At the same time, empirical models of central bank behavior focus almost entirely on linear interest rate reaction functions, which are derived directly from the linear-quadratic model of CB preferences ${ }^{2}$. Central banks, on their part, actively debate the extent to which different ways of conducting monetary policy (individual versus collective accountability in monetary policy councils, signalling through public statements, or the degree of openness in publishing forecasts) help or hinder the pursuit of policy objectives $^{3}$. But there is little dissent between CBs when it comes to the choice of primary policy target (the inflation target has become dominant), or on the need to stabilize both inflation and short-run fluctuations in the output gap.

This consensus view suggests that inflation, on the scale of the 1970s and early 1980s, is no longer a threat for those economies whose CBs have adopted, implicitly or explicitly, a system of inflation targeting. 'Flexible inflation targeters' will allow some deviation of inflation from the target pursued, in order to allow for output stabilization, but the weight given to price stability will not allow a marked increase in inflation. As argued by Blinder (1998), Vickers (1998), and McCallum (1997), independent CBs simply do not suffer from the 'inflation bias 'problem identified by Kydland and Prescott (1977) and Barro and Gordon (1983) ${ }^{4}$.

However, this view may be excessively optimistic, and to some extent

\footnotetext{
${ }^{1}$ See for example Svensson (1997), Goodhart (1999), Batini and Haldane (1999), Rudebusch and Svensson (1999).

${ }^{2}$ See Clarida et al. (1998, 2000) Muscatelli et al. (1999), Muscatelli and Trecroci (2000).

${ }^{3}$ This has led recently to alternative models of monetary policymaking institutions. For instance, the Bank of England has a policy-making body (the Monetary Policy Committee) which is individually accountable and which encourages public scrutiny of individual members. In contrast, the ECB maintains a focus on collective responsibility by its Council. This has led to a debate on the relative merits of the different models (see Buiter (1999), Issing (1999) and Cukierman (2001)).

${ }^{4}$ The only problem faced by CBs is then one of uncertainty: both surrounding the nature of shocks hitting the economy and 'long and variable lags' in the transmission mechanism (see Goodhart, 1999).
} 
might have been conditioned by the relatively benign inflation conditions of the 1990s. Cukierman $(2000,2002)$ show that the inflation bias may reappear even if policymakers target the natural level of employment and output. The problem arises whenever the CB is uncertain about the future state of the economy and is more worried about making policy errors that push output below than above its natural level. Jordan (2001) shows that a similar type of bias appears even if the $\mathrm{CB}$ has perfect but private information about shocks to the economy. The reason is that inflationary expectations internalize the stronger policy response to recessions leading expectations to be positive on average.

What are the bases for believing that policymakers might have asymmetric employment objectives? First, Blinder (1998) suggests, at least implicitly, that the political pressures faced by the Fed not to raise the interest rate when unemployment falls, are relatively more vigorous than pressures (if any) in the opposite direction when unemployment increases. ${ }^{5}$ A second base relies on the psychology of choice, and on the tendency of people to place a greater weight on the prospect of losses than on the prospect of gains in decision making. Kahneman and Tversky $(1979,1982,1984)$ and others have highlighted the fact that most individuals are likely to value objective gains of a given magnitude less than losses of the same magnitude and that this will lead to asymmetric behavior in choices under uncertainty.

In terms of the choices facing the $\mathrm{CB}$, even if the probability of positive shocks to employment equals that of negative shocks, if the $\mathrm{CB}$ is loss-averse with respect to output and frames decisions in terms of possible employment losses, this will lead to asymmetric behavior with respect to output/employment.

Of course framing of this type could also arise with respect to inflation. At times of high inflation a CB charged with price stability is likely to attach greater disutility to rates of inflation above the target than to rates of inflation at a similar distance below it. Nobay and Peel (1998) and Ruge-Murcia (2000) show that in such cases a deflationary bias may arise

Existing empirical evidence on asymmetric CB objectives is scant, mixed and varied. When asymmetries are present the evidence is sometimes consistent with asymmetric objectives with respect to inflation and in other cases

\footnotetext{
${ }^{5}$ Blinder (1998, pp.19-20) states that: "In most situations the CB will take far more political heat when it tightens pre-emptively to avoid higher inflation than when it eases pre-emptively to avoid higher unemployment".
} 
with asymmetric objectives with respect to the output gap. Dolado et al. (2000) estimate a variant of the Clarida et al. $(1998,2000)$ interest-rate reaction function for a number of central banks (USA, Germany, Spain, France), allowing for different interest-rate responses for positive and negative output and inflation movements. They find some evidence of asymmetric CB behavior with respect to the inflation objective, but only for the USA do they find any asymmetry in behavior vis-à-vis output movements. Using a Lucas type transmission mechanism Ruge-Murcia (2001) presents time series evidence that is consistent with the view that monetary policymakers in France and the USA are more averse to negative than to positive output gaps. Gerlach (2000) presents preliminary cross sectional evidence which points in a similar direction.

Asymmetric output gap losses lead to the emergence of a precautionary demand for expansions by monetary policymakers (Cukierman (2002)). Similarly, asymmetric losses from deviations of inflation from target lead to a precautionary demand for deflation (Nobay and Peel (1998) and RugeMurcia (2000)). This paper develops a methodology for dealing with both types of precautionary demands as an anchor for empirical work aimed at two main objectives: 1 . To test for the possible existence of asymmetries of either kind; 2. When asymmetries are present, to determine empirically, which of the two types of precautionary demands dominates the conduct of monetary policy. The theoretical framework focusses on the implications of asymmetries in objectives for interest rate reaction functions within a New-Keynesian framework of the type presented by Clarida, Gali and Gertler (1999). The specification of asymmetries in objectives is rather general unlike most recent papers on this topic. ${ }^{6}$

It is shown that both types of precautionary demands often lead to a reaction function that is convex in expected inflation and that there is a systematic relation between the concavity/convexity properties of this function with respect to the expected output gap and the dominant type of precautionary demand. Thus, although it reveals the existence of some asymmetry, an empirically estimated interest rate reaction function which is convex in expected inflation does not, by itself, provide a clue for the type of asymmetry. However the dominant type of asymmetry, and therefore of precautionary

\footnotetext{
${ }^{6}$ An exception is Geraats (1999). Except for her paper that focusses on somewhat different issues recent work on asymmetries in monetary policy either assumes a discontinuity at zero for the output gap (Cukierman $(2000,2002)$ ) or specifies losses by means of the Linex function (Nobay and Peel (1998) and Ruge-Murcia (2000, 2001)).
} 
demand, can be deduced from the curvature of the reaction function with respect to the expected output gap. In particular a reaction function that is concave in the expected output gap indicates that the precautionary demand for expansions dominates whereas a convex reaction function indicates that the precautionary demand for low inflation dominates.

To test the theory the estimates of interest-rate reaction functions are formulated so as to allow for the possibility of non-linear and asymmetric responses in both output and inflation. In addition, the econometric specification allows for a smooth transition of the slope of the function between different ranges of the expected values of inflation and of the output gap making it sufficiently flexible to capture a wide range of non-linear and asymmetric reactions. ${ }^{7}$ This methodology is applied to estimate interest rate reaction functions for four major industrialized economies (the USA, Japan, Germany and the UK) and to make inferences about the dominant type of precautionary demand in each case. These economies have experienced very different macroeconomic conditions over the last 20 years, and have had different institutional frameworks governing the conduct of monetary policy.

For the time period between 1980 and 2000 the evidence points to the existence of some asymmetry in the conduct of monetary policy in the US, Japan and the UK, but not in Germany. The reaction function is convex in the expected output gap in the US and the UK suggesting that the precautionary demand for low inflation dominated the conduct of monetary policy in those countries during this period. Reestimation over the latter period between 1985 and 2000 reveals interesting differences between the UK and the US. It still points to the same conclusion for the UK and for Japan, but reveals the emergence of a dominant precautionary demand for expansions in the US whose reaction function is now concave in the expected output gap.

Those results are consistent with the view that, after having established its price stability credentials during the early eighties, the Fed's policy became dominated, in the latter period, by a precautionary demand for expansions. By contrast monetary policy in the UK was dominated by the precautionary demand for low inflation also during the latter period, which is consistent with the fact that the process of inflation stabilization and of

\footnotetext{
${ }^{7}$ This contrasts with the Dolado et al. (2000) model, which only permits a discontinuous change in slope around some fixed trigger point like an announced inflation target or an output gap value of zero.
} 
reputation building in this country continued till much later This in turn lends support to the 'framing hypothesis': monetary policymakers are likely to place greater weight on the most imminent risk of loss. At times of disinflation, output loss becomes less important. Conversely during periods which are not characterized by credibility-building and disinflation, asymmetric preferences with respect to output re-emerge. These results support the notion that reports on the 'death of inflation' have been exaggerated.

The paper is organized as follows. Section 2 presents the theoretical framework and derives implications for the relationship between the type of precautionary motive that dominates monetary policy and the shape of the reaction function. Section 3 estimates a linear baseline reaction function, tests for the existence of non linearities and then parametrizes them explicitly. Section 4 presents estimates of the model for the 1atter, 1985 - 2000, period and show that the importance of asymmetric behavior varies between different periods (e.g. at times of disinflation, the output asymmetry becomes less important). Section 5 concludes.

\section{Theoretical Framework}

\subsection{Economic Structure}

The behavior of the economy is characterized by means of a Neo Keynesian, forward looking, sticky prices framework in which inflation and the output gap depend respectively on the expected future values of those variables and in which the policy instrument of the monetary authority is the nominal interest rate. A simple aggregate version of such a framework has recently been summarized compactly by Clarida et al. (1999) and is reproduced in what follows;

$$
\begin{gathered}
x_{t}=-\varphi\left(i_{t}-E_{t} \pi_{t+1}\right)+E_{t} x_{t+1}+g_{t} \\
\pi_{t}=\lambda x_{t}+\beta E_{t} \pi_{t+1}+u_{t}
\end{gathered}
$$

Here $x_{t}$ and $\pi_{t}$ are the output gap and inflation, $E_{t} x_{t+1}$ and $E_{t} \pi_{t+1}$ are the expected values of those variables conditioned on the information available in period $t, i_{t}$ is the nominal rate of interest, $g_{t}$ is a demand shock, $u_{t}$ is a cost shock and $\varphi, \lambda$ and $\beta$ are positive coefficients. The expected future 
output gap appears in the output gap equation to reflect the notion that, since individuals smooth consumption, expectations of higher consumption next period (associated with higher expected output) leads them to demand more current consumption, which raises current output.

As in stylized models of sticky staggered prices pioneered by Calvo (1983), current inflation depends on future expected inflation. In this type of models only a fraction of firms has the opportunity to adjusts its price each period and, due to costs of price adjustment, each firm adjusts its price at discrete intervals. Hence when it is given the chance to adjust its price the firm adjusts it by more the higher is expected future inflation. This interpretation implies that $\beta$ is a discount factor. The positive dependence of inflation on the output gap is based on the view that this gap is a measure of excess demand and is shared by both forward, as well as backward, looking models of the economy in which output is demand determined.

\subsection{General Specification of Asymmetric Objectives}

The objective of the monetary authority is to minimize

$$
E_{0} \sum_{t=0}^{\infty} \delta^{t} L_{t}
$$

where $\delta$ is the discount factor and $L_{t}$ is given by equation (4). ${ }^{8}$

$$
L_{t}=A f\left(x_{t}\right)+h\left(\pi_{t}-\pi^{*}\right)+C\left(i_{t}-i_{t-1}\right)^{2}
$$

Here $A$ and $C$ are positive coefficients, $\pi^{*}$ is the inflation target and the functions $f\left(x_{t}\right)$ and $h\left(\pi_{t}-\pi^{*}\right)$ possess the following properties.

$$
\begin{aligned}
f^{\prime}\left(x_{t}\right) & <0 \text { for } x_{t}<0, f^{\prime}\left(x_{t}\right) \geq 0 \text { for } x_{t} \geq 0, f(0)=f^{\prime}(0)=0, \\
f^{\prime \prime}\left(x_{t}\right) & >0, f^{\prime \prime \prime}\left(x_{t}\right) \leq 0 \\
h^{\prime}\left(\pi_{t}-\pi^{*}\right) & \leq 0 \text { for } \pi_{t}-\pi^{*} \leq 0, h^{\prime}\left(\pi_{t}-\pi^{*}\right)>0 \text { for } \pi_{t}-\pi^{*}>0 \\
h(0) & =h^{\prime}(0)=0, h^{\prime \prime}\left(\pi_{t}-\pi^{*}\right)>0, h^{\prime \prime \prime}\left(\pi_{t}-\pi^{*}\right) \geq 0
\end{aligned}
$$

\footnotetext{
${ }^{8}$ A similar specification of the loss function appears in Svensson (2000). The parameter $C$ measures the costs of interest rate variability. A theoretical rationale for the existence of costs of interest rate variability appears in Cukierman (1990) or chapter 7 of Cukierman (1992).
} 
where the tags attached to the functions $f\left(x_{t}\right)$ and $h\left(\pi_{t}-\pi^{*}\right)$ designate partial derivatives whose order is given by the number of tags. The specification in equation (5) states that losses from both the output gap and the inflation gap (the deviation of inflation from its target) attain their minimal levels when those two gaps are zero and that losses are larger, at least weakly, the larger the absolute value of the gaps. The first order partial derivatives of both $f\left(x_{t}\right)$ and $h\left(\pi_{t}-\pi^{*}\right)$ are zero when gaps are zero. As with the quadratic, the second partial derivatives are assumed to be positive, but unlike the quadratic $f\left(x_{t}\right)$ and $h\left(\pi_{t}-\pi^{*}\right)$ need not be symmetric around zero.

Potential asymmetries in objectives are introduced by means of the assumptions on the third partial derivatives. A negative value of $f^{\prime \prime \prime}\left(x_{t}\right)$ means that the marginal loss at a given negative output gap is larger than the marginal loss at a positive output gap with the same absolute value. It implies that policymakers have a precautionary demand for expansions. When $f^{\prime \prime \prime}\left(x_{t}\right)=0$ this precautionary demand is zero. ${ }^{9}$

A positive value of $h^{\prime \prime \prime}\left(\pi_{t}-\pi^{*}\right)$ means that, for a given absolute value of the deviation of inflation from its target, the marginal loss of a positive deviation is larger than the marginal loss of a negative deviations. It implies that policymakers are more averse to upward than to downward deviations from the target. Such behavior may arise in periods of inflation stabilization during which the buildup of credibility is a primary consideration. In the particular case $h^{\prime \prime \prime}\left(\pi_{t}-\pi^{*}\right)=0$ such aversion is absent.

\subsection{The policy process and the policy rule}

An important aspect of monetary policymaking is that the interest rate has to be chosen before the realization of economic shocks is known with certainty by policymakers. This fact is captured here by assuming that the realizations of the shocks $g_{t}$ and $u_{t}$ are unknown at the time policymakers pick the nominal interest rate $i_{t}$. The policy rule can be found by minimizing the expected value from equation (3) subject to the behavior of the economy as given by

\footnotetext{
${ }^{9}$ There is a strong analogy between the precautionary demand of policymakers for expansions and the precautionary demand for savings by consumers. Kimball (1990) shows that a necessary and sufficient condition for the existence of the latter is that the marginal utility of consumption or income be a convex function of income (a positive third partial derivative). Similarly, the condition $-f^{\infty}\left(x_{\mathrm{t}}\right)>0$, which is necessary and sufficient for the existence of a precautionary demand for expansions, means that the marginal utility, to policymakers, of an increase in output is a convex function of output.
} 
equations (1) and (2). Inserting those equations into equation (4), substituting the resulting expression into equation (3) and taking the expected value conditional on period's 0 information, the problem of the central bank is to choose the current interest rate $i_{0}$ and the sequence of future interest rates $i_{t}, t>0$ so as to minimize the following expression

$E_{0} \sum_{t=0}^{\infty} \delta^{t}\left\{\begin{array}{c}A f\left[-\varphi\left(i_{t}-E_{t} \pi_{t+1}\right)+E_{t} x_{t+1}+g_{t}\right]+ \\ h\left[\lambda\left(-\varphi\left(i_{t}-E_{t} \pi_{t+1}\right)+E_{t} x_{t+1}+g_{t}\right)+\beta E_{t} \pi_{t+1}+u_{t}\right]+\frac{C}{2}\left(i_{t}-i_{t-1}\right)^{2}\end{array}\right\}$.

The typical first order condition for an internal maximum is

$$
-\varphi A E_{0} f^{0}[.]-\varphi \lambda E_{0} h^{0}[.]+C\left(i_{t}-i_{t-1}\right)-\delta C\left(i_{t+1}-i_{t}\right)=0, \quad t=0,1,2, . .
$$

This string of conditions simultaneously determines the actual interest rate chosen in period 0 and in each of the subsequent periods as a function of expected future inflations and output gaps. But only the current choice of interest rate, $i_{0}$, is implemented in the current period.

\subsection{Comparative statics with respect to $E_{0} \pi_{1}$ and the effect of asymmetric objectives}

Totally differentiating the first order condition for $t=0$ in $(7)$ with respect to $E_{0} \pi_{1}$

$$
\begin{aligned}
& {\left[\varphi^{2} A E_{0} f_{0}^{\infty}[.]+\varphi^{2} \lambda^{2} E_{0} h_{0}^{\infty}[.]+(1+\delta) C\right] \frac{d i_{0}}{d E_{0} \pi_{1}}-\delta C \frac{d i_{1}}{d E_{0} \pi_{1}} } \\
= & \varphi^{2} A E_{0} f_{0}^{\infty}[.]+\left(\varphi^{2} \lambda^{2}+\beta\right) E_{0} h_{0}^{\infty}[.] .
\end{aligned}
$$

where

$$
\begin{aligned}
f_{0}^{\infty}[\cdot] & \equiv f^{\infty}\left[-\varphi\left(i_{0}-E_{0} \pi_{1}\right)+E_{0} x_{1}+g_{0}\right] \\
h_{0}^{\infty}[\cdot] & \equiv h^{\infty}\left[\lambda\left(-\varphi\left(i_{0}-E_{0} \pi_{1}\right)+E_{0} x_{1}+g_{0}\right)+E_{0} x_{1}+u_{0}\right] .
\end{aligned}
$$

We focus on the case in which the rate of time preference of policymakers 
is relatively high so that $\delta$ is small. ${ }^{10}$ In this case the solution for $\frac{d i_{0}}{d E_{0} \pi_{1}}$ from equation (8) is given approximately by

$\frac{d i_{0}}{d E_{0} \pi_{1}}=\frac{\varphi^{2} A E_{0} f_{0}^{\infty}[.]+\left(\varphi^{2} \lambda^{2}+\beta\right) E_{0} h_{0}^{\infty}[.]}{\varphi^{2} A E_{0} f_{0}^{\infty}[.]+\varphi^{2} \lambda^{2} E_{0} h_{0}^{\infty}[.]+C} \equiv \frac{\varphi^{2} A E_{0} f_{0}^{\infty}[.]+\left(\varphi^{2} \lambda^{2}+\beta\right) E_{0} h_{0}^{\infty}[.]}{D}$.

Since, as stated in equation (5), all the second partial derivatives are positive this expression is positive, implying that policymakers react to an increase in expected inflation by raising the nominal interest rate. If $E_{0} h_{0}^{\infty}$ is sufficiently large and/or $C$ sufficiently small in comparison to $\beta$, the nominal rate increases by more than the increase in inflationary expectations implying that the expression in equation (10) is also larger than one. One implication of this observation is that, if the costs of deviating from the inflation target increase sufficiently quickly with the size of the deviation $\left(E_{0} h_{0}^{\infty}\right.$ is large), an increase in expected inflation induces policymakers to raise the ex ante real rate of interest.

To evaluate the impact of asymmetric objectives on the extent to which the response of the interest rate to a change in expected inflation is non linear we now differentiate the expression in equation (10) with respect to $E_{0} \pi_{1}$ again. After some algebra the resulting expression is

$$
\frac{d^{2} i_{0}}{d\left(E_{0} \pi_{1}\right)^{2}}=\frac{1}{D^{2}}\left\{\begin{array}{c}
\varphi^{3} A\left(C-\beta E_{0} h_{0}^{\infty}\right) E_{0} f_{0}^{\infty}+ \\
(\varphi \lambda+\beta)\left[\left(\varphi^{2} \lambda+\beta\right) C+\varphi^{2} \beta A E_{0} f_{0}^{\infty}\right] E_{0} h_{0}^{\infty}
\end{array}\right\}
$$

where the functions' brackets have been deleted to simplify notation. Provided asymmetries in objectives operate with respect to both inflation and

\footnotetext{
${ }^{10}$ Preliminary simulations, using a Linex specification of asymmetric preferences and recent parameter estimates for the US, support the view that the optimal interest rate rule is relatively insensitive to the precise value of the discount factor over a wide range of discount factors. Using simulations based on estimates of the New Keynesian model from Gali et al. (2001) for the USA, and values of the discount rate from 2\%-10\% (a discount factor of 0.90-0.98) we find that setting the discount factor equal to zero only leads to minor changes in the optimal interest rule (of the order of 10-20 basis points), and even that only for 1-3 quarters.

Jordan (2001, p. 41) expresses the view that monetary policymakers tend to have relatively short term horizons.
} 
the output gap $E_{0} f_{0}^{\infty}<0$ and $E_{0} h_{0}^{\infty}>0$ implying that the model is sufficiently general to accommodate precautionary demands for both expansions, as well as for inflation rates below the (inflation) target. The coefficient of $E_{0} h_{0}^{\infty}$ is positive while the coefficient of $E_{0} f_{0}^{\infty}$ may be of either sign depending on the relative magnitudes of $C$ and of $\beta E_{0} h_{0}^{\infty}$. Interestingly, if the cost of interest rate variability as measured by $C$ is not too large, both asymmetries tend to make the response of the interest rate to increased inflationary expectations higher when expected inflation is higher. In particular, this may be true even if the central bank has a precautionary demand only for expansions without any asymmetry with respect to the inflation objective. If both asymmetries are absent, $E_{0} f_{0}^{\infty}=E_{0} h_{0}^{\infty}=0$ and the response of the interest rate to expected inflation is predicted to be linear. Thus, an interest rate policy reaction function that is convex in expected inflation implies that some type of asymmetry in objectives is present, but it does not, by itself, provide a clue for the type of asymmetry ${ }^{11}$.

\subsection{Comparative statics with respect to $E_{0} x_{1}$ and the differential effects of different types of asymmetries}

Totally differentiating the first order condition for $t=0$ in $(7)$ with respect to $E_{0} x_{1}$

$$
\begin{aligned}
& {\left[\varphi^{2} A E_{0} f_{0}^{\infty}[.]+\varphi^{2} \lambda^{2} E_{0} h_{0}^{\infty}[.]+(1+\delta) C\right] \frac{d i_{0}}{d E_{0} x_{1}}-\delta C \frac{d i_{1}}{d E_{0} x_{1}} } \\
= & \varphi A E_{0} f_{0}^{\infty}[.]+\varphi \lambda^{2} E_{0} h_{0}^{\infty}[\cdot] .
\end{aligned}
$$

For sufficiently small $\delta^{\prime} s$ this can be rearranged to yield the following approximate expression for the reaction of the interest rate to the expected output gap

$$
\frac{d i_{0}}{d E_{0} x_{1}}=\frac{\varphi A E_{0} f_{0}^{\infty}[.]+\varphi \lambda^{2} E_{0} h_{0}^{\infty}[.]}{\varphi^{2} A E_{0} f_{0}^{\infty}[.]+\varphi^{2} \lambda^{2} E_{0} h_{0}^{\infty}[.]+C} \equiv \frac{\varphi A E_{0} f_{0}^{\infty}[.]+\varphi \lambda^{2} E_{0} h_{0}^{\infty}[.]}{D} .
$$

\footnotetext{
${ }^{11}$ Note, however, that if $\varphi$ is small (as it typically tends to be in estimates of the New Keynesian model, see Gali et al., 2001), then the asymmetry in inflation, $E_{0} h_{0}^{\infty}$ tends to dominate the asymmetry in output, $E_{0} f_{0}$.
} 
The specification of the segments $h($.$) and f($.$) of the losses from deviations$ of inflation and output from their respective targets in equation (5) implies that the response of the interest rate to an increase in the expected output gap is positive. To evaluate the effects of the precautionary demands for expansion and for price stability on the form of the functional relationship between those to variables we differentiate the expression in equation (13) again with respect to $E_{0} x_{1}$. After some algebra the resulting expression is

$$
\frac{d^{2} i_{0}}{d\left(E_{0} x_{1}\right)^{2}}=\frac{\varphi C}{D^{2}}\left\{A E_{0} f_{0}^{\infty}+\lambda^{3} E_{0} h_{0}^{\infty}\right\}
$$

The coefficients of both $E_{0} f_{0}^{\infty}$ and of $E_{0} h_{0}^{\infty}$ are positive. Since $E_{0} f_{0}^{\infty}<0$ and $E_{0} h_{0}^{\infty}>0$ the sign of this expression is determined by the relative importance of the precautionary demand for expansions (as measured by the absolute value of $E_{0} f_{0}$ ) and of the precautionary demand for low inflation as measured by $E_{0} h_{0}^{\infty}$. If the first asymmetry dominates, the interest rate reaction function should be a concave function of the expected output gap, whereas, if the second dominates, it should be a convex function of the expected output gap. In the absence of either type of asymmetry the reaction should be linear in the expected output gap. ${ }^{12}$ Thus, the type of non-linearity in the reaction with respect to the expected output gap can be used to find out which type of asymmetry is stronger. Obviously empirical results may vary across different countries.

\section{Estimating an Interest Rate Reaction Func- tion Model with Non-linear Responses}

The major empirically testable implications of the model are: 1 . In the absence of asymmetries in objectives, the reaction function should be linear in both expected inflation and the expected output gap, 2. In the presence of asymmetries of objectives of any type the partial reaction of the interest rate to expected inflation is a convex function of expected inflation, ${ }^{13} 3$. In the

\footnotetext{
${ }^{12}$ Note that the reaction to $E_{0} x_{1}$ may be linear even if both precautionary demands are present, provided those two effects offset each other.

${ }^{13}$ Strictly speaking this is true provided the cost of adjusting the interest rate is not excessively large.
} 
presence of some asymmetry, the partial reaction of the interest rate to the expected output gap is a concave or a convex function of the expected output gap depending on whether the asymmetry of losses from negative output gaps is stronger or weaker than the asymmetry of losses from inflation rates above the target.

To test those implications we estimate reaction functions for short-term interest rates (the federal funds rate for the US and call money rates for other countries) for the period ${ }^{14} 1980-2000$, using quarterly data (the data series employed are detailed in the Data Appendix). We begin by presenting results from the estimation of a standard linear interest reaction function as a baseline against which to evaluate non-linear/asymmetric interest rate reaction functions.

\subsection{A Standard Linear Reaction Function}

The first order condition in equation (7) specialized to period 0 implies that, for sufficiently small $\delta^{\prime} s$, the current interest rate is determined by the expected future values of inflation, of the output gap ${ }^{15}$, and by the value of the previous period's interest rate. In the absence of asymmetries $\left(E_{0} h_{0}^{\infty}=\right.$ $\left.E_{0} f_{0}=0\right)$ the non linear terms in equations (11) and (14) are both zero and, for estimation purposes, the reaction function can be approximated by the following linear relation

$$
i_{t}=\alpha+\beta\left(E\left[\pi_{t, k} \mid \Omega_{t}\right]-\pi^{*}\right)+\gamma E\left[x_{t, q} \mid \Omega_{t}\right]+\rho i_{t-1}+v_{t}
$$

where $v_{t}$ is an exogenous interest rate control error. Comparative statics of $i_{t}$ with respect to $i_{t-1}$ applied to the first order condition in equation (11)

\footnotetext{
${ }^{14}$ In the case of Germany, the ECB took over control of monetary policy at the beginning of EMU. Nevertheless, there is substantial casual evidence to suggest that until the beginning of EMU in 1999, the Bundesbank continued to pursue its domestic objectives in setting interest rates.

${ }^{15}$ As can be seen from the data Appendix, we use official estimates of potential output (OECD, BEA) to construct series for the output gap. In contrast, Muscatelli et al. (1999) use a Kalman Filter based estimation to allow for gradual learning by the authorities of changes in the processes generating inflation and the output gap. Using official data on the output gap makes our results more directly comparable to most of the existing empirical literature on interest rate reaction functions.
} 
imply that $\rho$ is positive but smaller than one. ${ }^{16}$ Except for the fact that the partial adjustment of the interest rate follows directly from the objective function of the CB this specification is similar to that provided by Clarida et al. $(1998,2000) .{ }^{17}$ Adding and subtracting $\beta \pi_{t, k}$ and $\gamma x_{t, q}$ to equation (15) and rearranging

$$
i_{t}=\widetilde{\alpha}+\beta \pi_{t, k}+\gamma x_{t, q}+\rho i_{t-1}+\varepsilon_{t}
$$

where $\widetilde{\alpha}=\alpha-\beta \pi^{*}$ and the error term $\varepsilon_{t}$ contains the forecast errors and the interest rate control error:

$$
\varepsilon_{t}=-\left[\beta\left(\pi_{t, k}-E\left[\pi_{t, k} \mid \Omega_{t}\right]\right)+\gamma\left(x_{t, q}-E\left[x_{t, q} \mid \Omega_{t}\right]\right)\right]+v_{t} .
$$

To estimate equation (16) we employ Hansen's (1982) Generalized Method of Moments (GMM), using as instruments five lags of the policy instrument and of the policy targets (output and inflation). Clarida et al. experiment with various leads for the output gap and expected inflation, but in fact $\mathrm{q}=\mathrm{k}=1$ seems to fit the data reasonably well, and the estimates of the parameters are not too sensitive to changes in $\mathrm{q}$ and $\mathrm{k}$ over the range 1 to 4 quarters ${ }^{18}$.

The estimates obtained for equation (16) for all four countries, using GMM are shown in Table 1. Four lags of the explanatory variables are used as instruments in the estimation.

\footnotetext{
16

$$
0<\frac{d i_{0}}{d E_{0} \pi_{1}}=\frac{C}{\varphi^{2} A E_{0} f_{0}^{\infty}[.]+\varphi^{2} \lambda^{2} E_{0} h_{0}^{\infty}[.]+C}<1
$$

${ }^{17}$ In that respect our specification is in the spirit of Svensson (2000) and Muscatelli et. al. (1999) who include the costs of interest rate adjustment in the optimization exercise.

${ }^{18}$ The lack of sensitivity of the result to the choice of lead period is probably due to the high degree of serial correlation in these series.
} 
Table 1: GMM Estimates of Linear Interest Rate Reaction Functions (Long-Run Coefficients)

\begin{tabular}{||c|l|l|l|l|l|l||}
\hline \hline Country & $\widehat{\widetilde{\alpha}} /(1-\widehat{\rho})$ & $\widehat{\beta} /(1-\widehat{\rho})$ & $\widehat{\gamma} /(1-\widehat{\rho})$ & $\widehat{\rho}$ & Statistics & $\begin{array}{l}\text { Sample } \\
\text { Period }\end{array}$ \\
\hline USA & 1.32 & 1.88 & 0.69 & 0.80 & $\sigma=1.04$, & $1979: 3-1999: 4$ \\
& $(1.60)$ & $(0.61)$ & $(0.31)$ & $(0.06)$ & $J(12)=0.29$ & \\
\hline Germany & -5.90 & 3.38 & 3.74 & 0.92 & $\sigma=0.70$, & $1979: 3-2000: 1$ \\
& $(7.72)$ & $(1.98)$ & $(3.71)$ & $(0.07)$ & $J(12)=0.09$ & \\
\hline Japan & 1.36 & 1.72 & 0.17 & 0.88 & $\sigma=0.60$, & $1979: 3-2000: 1$ \\
& $(1.05)$ & $(0.62)$ & $(0.08)$ & $(0.03)$ & $J(12)=0.16$ & \\
\hline UK & 4.32 & 1.03 & 0.69 & 0.79 & $\sigma=1.08$, & $1979: 3-1999: 3$ \\
& $(0.83)$ & $(0.17)$ & $(0.26)$ & $(0.05)$ & $J(12)=0.10$ & \\
\hline \hline
\end{tabular}

Notes: Numbers in brackets indicate standard errors (using a consistent covariance matrix for heteroscedasticity and serial correlation); $\sigma$ indicates the standard error of the estimate; J(n) is Hansen's test of the model's overidentifying restrictions. It is distributed as a $\chi^{2}(n)$ variate under the null hypothesis of valid overidentifying restrictions.

The estimates in Table 1 are consistent with those reported in Clarida et al, allowing for the slightly different sample period used here. Excluding the UK, all the countries have been characterized during the last two decades by a long-run response of interest rates to expected inflation that is larger than unity. In the case of the UK the point estimate for $\widehat{\beta} /(1-\widehat{\rho})$ is close to one, which is consistent with the fact that inflation was brought under control much later. The interest rate response to the expected output gap is not significant in the case of Germany, but is significant in the case of all remaining countries. Note also that the UK has a higher equilibrium real interest rate under this model than Japan, Germany and the US where it is not significantly different from zero. Clarida et al have used similar estimates to support the conclusion that a number of major industrialized economies have, de facto, followed an implicit forward-looking inflation targeting policy.

\subsection{Evidence of non-linear or asymmetric behavior}

What evidence is there that linear models of the type estimated by Clarida et al. $(1998,2000)$ and reported above do not capture the full story as far as interest rate decision-making is concerned? To provide a preliminary answer this question we use a number of diagnostic tests. In particular we focus on 
a class of residual-based tests designed to verify whether non-linear effects are present (see Granger and Terasvirta, 1993) ${ }^{19}$.

Using the fitted residuals from (16), one fits the auxiliary model:

$$
\widehat{\varepsilon}_{t}=\boldsymbol{\delta}_{0}^{\prime} \mathbf{x}_{t}+\boldsymbol{\delta}_{1}^{\prime} \mathbf{x}_{t} z_{t d}+\boldsymbol{\delta}_{2}^{\prime} \mathbf{x}_{t}\left(z_{t d}\right)^{2}+\boldsymbol{\delta}_{3}^{\prime} \mathbf{x}_{t}\left(z_{t d}\right)^{3}
$$

where $\mathbf{X}_{t}$ is the vector of regressors in the original model, and $z_{t d}$ is a 'transition variable' which may be either a lagged dependent variable (the interest rate) or any of the variables in the model (inflation, output gap), or indeed any other variable which might explain non-linear behavior in the model. The results from applying these tests are shown in Table 2. The tests show that in all four countries there is evidence supporting some non-linearity in the response of the interest rate. The only exception is Germany, for which the tests are only marginally significant, and are not significant when output or inflation is used as the transition variable.

There are several points to note about these tests. First, we are performing these tests against a variety of possible transition variables. We will focus, in what follows, primarily on using either the output gap or the level of inflation as transition variables. The reason is that the theoretical framework implies that whether the interest rate reaction function is a convex or concave function of the output gap and inflation carries implications for the dominant type of asymmetry. Second, because we do not know the true nature of the non-linear model under the alternative hypothesis (and the appropriate transition variable(s)), the true significance level (size) of these multiple non-linearity tests cannot be known with precision. Hence they should be treated as indicative tests ${ }^{20}$. In other words, the statistical test described here is a generic test which has power against different types of non-linear behavior.

\footnotetext{
${ }^{19}$ Granger and Terasvirta stress that this form of test has power against a variety of non-linear effects, such as a logistic-smooth-transition or an exponential-smooth-transition model.

${ }^{20}$ In general these tests are only valid when the residuals are obtained from least-squares estimation procedures. As an alternative, we tested whether the non-linear terms were significant when added directly to the GMM model. They were still significant. In order to verify that the non-linearity tests are not picking up any omitted variables in the reaction function, we also tried to add the nonlinear terms when the reaction functions also included a lagged value of inflation and output. Again, the nonlinear terms were still found to be significant. We are grateful to Adrian Pagan for suggesting these additional tests.
} 
Table 2: Tests of Non-linear Interest Rate Responses

\begin{tabular}{||lll||}
\hline \hline USA & $H_{0}: \boldsymbol{\delta}_{1}=0$ & $H_{0}: \boldsymbol{\delta}_{2}=\boldsymbol{\delta}_{3}=0$ \\
$z_{t d}=x$ & 0.43 & $3.02^{* * *}$ \\
$z_{t d}=\pi$ & $3.52^{* *}$ & $6.14^{* * *}$ \\
$z_{t d}=i_{t-1}$ & $3.58^{* *}$ & $4.47^{* * *}$ \\
\hline \hline \hline Germany & $H_{0}: \boldsymbol{\delta}_{1}=0$ & $H_{0}: \boldsymbol{\delta}_{2}=\boldsymbol{\delta}_{3}=0$ \\
$z_{t d}=x$ & 1.08 & 1.77 \\
$z_{t d}=\pi$ & 0.98 & 2.08 \\
$z_{t d}=i_{t-1}$ & $2.37^{*}$ & $13.15^{* * *}$ \\
\hline \hline \hline Japan & $H_{0}: \boldsymbol{\delta}_{1}=0$ & $H_{0}: \boldsymbol{\delta}_{2}=\boldsymbol{\delta}_{3}=0$ \\
$z_{t d}=x$ & 0.28 & 1.05 \\
$z_{t d}=\pi$ & $17.39^{* * *}$ & $11.19^{* * *}$ \\
$z_{t d}=i_{t-1}$ & $19.17^{* * *}$ & $12.93^{* * *}$ \\
\hline \hline \hline $\mathrm{UK}$ & $H_{0}: \boldsymbol{\delta}_{1}=0$ & $H_{0}: \boldsymbol{\delta}_{2}=\boldsymbol{\delta}_{3}=0$ \\
$z_{t d}=x$ & 0.65 & $2.51^{* *}$ \\
$z_{t d}=\pi$ & 1.20 & $3.30^{* * *}$ \\
$z_{t d}=i_{t-1}$ & 1.27 & $3.04^{* * *}$ \\
\hline \hline
\end{tabular}

Note: The $\delta_{1}=0$ test is distributed as an $\mathrm{F}(3,69)$ variate under the null, whilst the $\delta_{2}=\delta_{3}=0$ test is distributed as a $\mathrm{F}(6,69)$ variate under the null. $\mathrm{A}(*),(* *),\left({ }^{* *}\right)$ indicates that the null hypothesis of a zero restriction is rejected at respectively the $10 \%$, $5 \%$ or $1 \%$ level.

\subsection{A model of Asymmetry with Non-linear Responses}

The tests in section 3.2 suggest that an alternative interest rate reaction function to the linear one might be appropriate. A variety of different types of models can be constructed to capture asymmetric/non-linear interest rate responses. In experimenting with these models, we concentrated our attention on smooth-transition models, i.e. models which predict a gradual switch from one regime to the other. In contrast to threshold models, which predict a sudden switch between regimes, smooth-transition regressions (STR) use particular functional forms to specify the way in which an economy moves from one regime to another. In our case STR appear to be preferable to threshold models since it is unlikely that over the 20 years sample period the switch point, or threshold, for the reaction of monetary policy has remained 
unchanged as both the individuals involved in decision-making and the objectives of policy have changed ${ }^{21}$ In addition, the notion of 'framing' discussed in the introduction suggests that policymakers are likely to develop subjective notions of risk vis-a-vis the inflation and output targets, and that these notions of riskiness are likely to evolve gradually over time. It is unlikely that, after passing a particular threshold for inflation or the output gap, CB behavior will change in a discontinuous manner. Hence, STR models seem as more appropriate for the analysis of non-linear and asymmetric behavior.

A smooth-transition regression (STR) model can be built following the modelling strategy proposed in Granger and Terasvirta (1993). A version of the reaction function in equation (16) that allows for a smooth transition specification of non linearities is given by

$$
i_{t}=\widetilde{\alpha}+\beta_{1} \pi_{t, 1}+\gamma_{1} x_{t, 1}+\left\{\beta_{2} \pi_{t, 1}+\gamma_{2} x_{t, 1}\right\} F\left(z_{t}\right)+\rho i_{t-1}+\varepsilon_{t}
$$

where $z_{t}$ is the variable which determines the transition and $F\left(z_{t}\right)$ is an appropriate non linear and continuous function of $z_{t}$. Granger and Terasvirta (1993) propose either the logistic or exponential functions to model the smooth transition (the so-called LSTR models). ${ }^{22}$ However, we obtained a better fit for our data using a hyperbolic tangent (tanh) function to capture the gradual transition between regimes (such a parametrization has been proposed by Bacon and Watts (1971), and Seber and Wild (1989)). The hyperbolic tangent smooth transition regression (HTSTR) assumes the following form for $F\left(z_{t}\right)$ :

$$
F\left(z_{t}\right)=\delta_{1} \tanh \left(\psi\left(z_{t}-\delta_{2}\right)\right) .
$$

The theory, as well as the tests in Table 2 suggest that the expected values of both the output gap and inflation might be appropriate transition variables. In fact, equation (18) involves a more restrictive specification than necessary

\footnotetext{
${ }^{21}$ Dolado et al. (2000) partly recognize this by allowing the (unknown) switch point for inflation to be determined by official inflation targets.

${ }^{22}$ The logistic (L-STR) model assumes

$$
F\left(z_{\mathrm{t}}\right)=\frac{1}{1+\exp \left(-\delta_{1}\left(z_{\mathrm{t}}-\delta_{2}\right)\right)} .
$$

Granger and Terasvirta also consider exponential STR models (ESTAR), but these are less appropriate for our purposes because of the form of the exponential function.
} 
since it suggests that a single transition variable (either the output gap or inflation) govern the non-linear responses with respect to both output and inflation. In practice, it might be the case that both large deviations from the inflation target or from the desired level of output will generate changes in the slope of the reaction function. In order to allow for asymmetries in both output and inflation to be triggered independently by transitions in both output and inflation, we respecify equation (18) as follows:

$$
i_{t}=\widetilde{\alpha}+\beta_{1} \pi_{t, 1}+\gamma_{1} x_{t, 1}+\beta_{2} \pi_{t, 1} F_{\pi}\left(\pi_{t, 1}\right)+\gamma_{2} x_{t, 1} F_{x}\left(x_{t, 1}\right)+\rho i_{t-1}+\varepsilon_{t}
$$

where $F($.$) is defined in equation (19) and the subscripts \pi$ and $x$ that are attached to $F($.$) allow for the possibility that the parameters \psi, \delta_{1}$ and $\delta_{2}$ vary depending on whether the variable which determines the transition is the output gap or inflation.

Equation (20) has the following properties: As inflation varies around the threshold $\delta_{2}$, the value of the hyperbolic tangent function varies between -1 and 1. Suppose for instance that $\delta_{2}=4 \%$, and that $\psi=1$, and $\delta_{1}=1$. At low inflation rates (approximately $2 \%$ below the threshold the tanh function is close to its lower asymptote of -1 ), the long-run response of the nominal interest rate to inflation is given by $\left(\beta_{1}-\beta_{2}\right)$. In contrast, at high inflation rates (approximately $2 \%$ above the threshold, i.e. at $6 \%$ inflation, the tanh function is close to its upper asymptote of 1 ), the nominal interest rate response to expected inflation is given by $\left(\beta_{1}+\beta_{2}\right)$. In the interval between these two asymptotes, the response lies somewhere in between these two values. In Section 3.5, having estimated the model, we shall illustrate how the response function varies over different values of output and inflation using graph plots.

\subsection{Estimating a HTSTR Model}

Equation (20) is estimated by GMM. As before, we use five lags of all the explanatory variables in the estimation. Table 3 reports the estimated parameters. Equation (20) is underidentified unless we fix a value for $\delta_{1}$. The reported estimates are for $\delta_{1}=1$. As far as the values of $\delta_{2}$ and $\psi$ are concerned, we conducted a grid search, as free estimation of $\delta_{2}$ and $\psi$ led to convergence problems with the non-linear optimisation algorithm. We selected the value of $\delta_{2}$ and $\psi$ which provided the best fit. In the case of $\psi$, as 
we shall see below, a value which is less than unity ensures that the functions $x_{t, 1} F_{x}\left(x_{t, 1}\right)$ and $\pi_{t, 1} F_{\pi}\left(\pi_{t, 1}\right)$ are convex for the range of all of our observations. In general, we found that estimating our models setting $\psi=0.25$ provided the best $\mathrm{fit}^{23}$. This implies that these functions are convex for the range $\left(\delta_{2}-4 \%, \delta_{2}+4 \%\right)$, which covers $95-100 \%$ of all our observations for inflation and output.

\footnotetext{
${ }^{23}$ We tried a grid search between $\psi=0.4$ and $\psi=0.15$.
} 
Table 3: GMM Estimates of Smooth-Transition non-Linear Reaction Functions

\begin{tabular}{|c|c|c|c|c|c|c|c|c|}
\hline 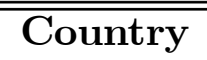 & \multicolumn{6}{|c|}{ Short-run Coefficients } & \multirow[t]{2}{*}{ Statistics } & \multirow{2}{*}{$\begin{array}{l}\text { Sample } \\
\text { Period }\end{array}$} \\
\hline & $\widetilde{\widetilde{\alpha}}$ & $\widehat{\beta}_{1}$ & \multicolumn{2}{|c|}{$\widehat{\beta}_{2}$} & $\widehat{\gamma}_{1}$ & $\widehat{\gamma}_{2}$ & & \\
\hline USA & $\begin{array}{l}0.67 \\
(0.34)\end{array}$ & $\begin{array}{l}0.13 \\
(0.05)\end{array}$ & \multicolumn{2}{|c|}{$\begin{array}{l}0.13 \\
(0.05)\end{array}$} & $\begin{array}{l}0.08 \\
(0.03)\end{array}$ & $\begin{array}{c}-0.11 \\
(0.08)\end{array}$ & $\begin{array}{l}\sigma=1.03 \\
J(10)= \\
18.3\end{array}$ & $\begin{array}{l}\text { 1979:3- } \\
\text { 1999:4 }\end{array}$ \\
\hline Germany & $\begin{array}{l}0.39 \\
(0.24)\end{array}$ & $\begin{array}{l}0.22 \\
(0.09)\end{array}$ & \multicolumn{2}{|c|}{$\begin{array}{l}0.17 \\
(0.10)\end{array}$} & $\begin{array}{l}0.11 \\
(0.03)\end{array}$ & $\begin{array}{l}0.04 \\
(0.06)\end{array}$ & $\begin{array}{l}\sigma=0.61, \\
J(10) \quad= \\
2.43\end{array}$ & $\begin{array}{l}1979: 3- \\
2000: 1\end{array}$ \\
\hline Japan & $\begin{array}{l}0.16 \\
(0.09)\end{array}$ & $\begin{array}{l}0.27 \\
(0.06)\end{array}$ & \multicolumn{2}{|c|}{$\begin{array}{l}0.03 \\
(0.10)\end{array}$} & $\begin{array}{l}0.14 \\
(0.05)\end{array}$ & $\begin{array}{l}0.14 \\
(0.05)\end{array}$ & $\begin{array}{l}\sigma=0.59 \\
J(10)= \\
7.33\end{array}$ & $\begin{array}{l}\text { 1979:3- } \\
2000: 1\end{array}$ \\
\hline UK & $\begin{array}{l}1.44 \\
(0.36)\end{array}$ & $\begin{array}{l}0.10 \\
(0.02)\end{array}$ & \multicolumn{2}{|c|}{$\begin{array}{l}0.10 \\
(0.02)\end{array}$} & $\begin{array}{l}0.11 \\
(0.04)\end{array}$ & $\begin{array}{l}0.11 \\
(0.04)\end{array}$ & $\begin{array}{l}\sigma=1.12 \\
J(10)= \\
15.6\end{array}$ & $\begin{array}{l}1979: 3- \\
1999: 3\end{array}$ \\
\hline Country & \multicolumn{8}{|c|}{ "Long-run Coefficients } \\
\hline & $\widehat{\widetilde{\alpha}} /(1-\widehat{\rho})$ & \multicolumn{2}{|c|}{$\widehat{\beta}_{1} /(1-\widehat{\rho})$} & \multicolumn{2}{|c|}{$\widehat{\overline{\beta_{2}} /(1-\widehat{\rho})}$} & 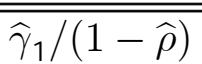 & $\widehat{\gamma}_{2} /(1-\widehat{\rho})$ & $\widehat{\rho}$ \\
\hline USA & $\begin{array}{l}5.03 \\
(1.08)\end{array}$ & \multicolumn{2}{|c|}{$\begin{array}{l}1.00 \\
(0.34)\end{array}$} & \multicolumn{2}{|c|}{$\begin{array}{l}1.00 \\
(0.34)\end{array}$} & $\begin{array}{l}0.60 \\
(0.44)\end{array}$ & $\begin{array}{l}-0.82 \\
(0.84)\end{array}$ & $\begin{array}{l}0.86 \\
(0.08)\end{array}$ \\
\hline Germany & $\begin{array}{l}2.16 \\
(0.90)\end{array}$ & \multicolumn{2}{|c|}{$\begin{array}{l}1.21 \\
(0.34)\end{array}$} & \multicolumn{2}{|c|}{$\begin{array}{l}0.94 \\
(0.48)\end{array}$} & $\begin{array}{l}0.58 \\
(0.25)\end{array}$ & $\begin{array}{l}0.21 \\
(0.31)\end{array}$ & $\begin{array}{l}0.82 \\
(0.06)\end{array}$ \\
\hline Japan & $\begin{array}{l}1.03 \\
(0.43)\end{array}$ & \multicolumn{2}{|c|}{$\begin{array}{l}1.74 \\
(0.30)\end{array}$} & \multicolumn{2}{|c|}{$\begin{array}{l}0.23 \\
(0.65)\end{array}$} & $\begin{array}{l}0.91 \\
(0.41)\end{array}$ & $\begin{array}{l}0.91 \\
(0.41)\end{array}$ & $\begin{array}{l}0.85 \\
(0.04)\end{array}$ \\
\hline UK & $\begin{array}{l}6.00 \\
(0.60)\end{array}$ & \multicolumn{2}{|c|}{$\begin{array}{l}0.41 \\
(0.06)\end{array}$} & \multicolumn{2}{|c|}{$\begin{array}{l}0.41 \\
(0.06)\end{array}$} & $\begin{array}{l}0.47 \\
(0.16)\end{array}$ & $\begin{array}{l}0.47 \\
(0.16)\end{array}$ & $\begin{array}{l}0.76 \\
(0.05)\end{array}$ \\
\hline
\end{tabular}

Notes: Numbers in parenthesis indicate standard errors (using a consistent covariance matrix for heteroscedasticity and serial correlation); $\sigma$ indicates the standard error of the estimate; $\mathrm{J}(\mathrm{n})$ is Hansen's test of the model's overidentifying restrictions, which is distributed as a $\chi^{2}(n)$ variate under the null hypothesis of valid overidentifying restrictions. The stars that are attached in some cases to the short run coefficients mean that those coefficients are significant at the 0.05 level of significance. 
Except for Japan the best fit was obtained with a value of $\delta_{2}=4 \%$ for the inflation asymmetry, and $\delta_{2}=0$ in the case of the output gap asymmetry. To be precise, the monetary authorities appear to be asymmetric as between positive and negative values of the output gap, and between situations of high inflation (inflation above 4\%) and situations of low inflation (below 4\%). In the case of Japan during the post-1985 period the best fit was obtained for a value of $\delta_{2}$ of $2 \%^{24}$. In all cases we tested whether a more parsimonious model could be fitted, by testing the restrictions $\widehat{\beta}_{1}=\widehat{\beta}_{2}$ and $\widehat{\gamma}_{1}=\widehat{\gamma}_{2}$. In the case of the UK, this restriction was accepted. For the USA only the restriction $\widehat{\beta}_{1}=\widehat{\beta}_{2}$ was not rejected, for Japan only $\widehat{\gamma}_{1}=\widehat{\gamma}_{2}$ was not rejected, and in the case of Germany both restrictions were rejected.

There are several important points to note about those estimates of the short run coefficients. First, in the case of the US and the UK there are clear signs of non-linearities as the non-linear effect on inflation is significant in the former case, and on both inflation and output in the latter case. In the case of Japan there is a non-linear output effect, but not a significant non-linear inflation effect. The estimated parameters on the non-linear terms in the case of Germany are insignificant. As we shall see in the next section, the Japanese estimates show a more marked non-linearity also for the inflation term if only the latter part of the sample is used (post-1985), indicating that non-linear/asymmetric effects have become more important since the mid1980s. In the case of Germany no improvement could be found to the above model. This confirms the findings in Table 2 which show that non-linearities do not seem to be important in the case of Germany. The Bundesbank's behavior does not appear to have been subject to asymmetries, unlike that of the Fed, the UK authorities ${ }^{25}$, and the Bank of Japan.

To illustrate the nature of the asymmetric behavior implied by these estimates, we can plot the reaction function in three-dimensional space $(x, \pi, i)$ for the USA. This is shown in Figure 1, where the vertical axis shows the long-run value of the interest rate for given combinations of the output gap and inflation. Hence the asymmetric/non-linear reaction function of Table 3 , which is shown as a curved plane.

Figure 1 shows that the asymmetry that seems to be present in US policy was mainly on inflation. Interest rates only begin to increase more sharply as inflation rises towards $4 \%$, and below $2 \%$ the response tends to flatten out,

\footnotetext{
${ }^{24}$ This is probably because during this period inflation in Japan rarely exceeded 2-3\%.

${ }^{25}$ The UK government until 1997, then the independent Bank of England.
} 


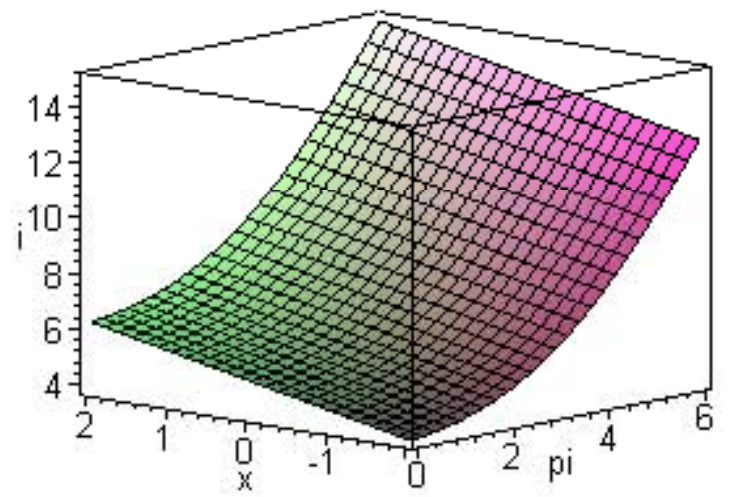

Figure 1: Non-Linear Reaction Functions, USA 1979-2000

suggesting that interest rates tend to reach a floor. In general, the implied response of the asymmetric model to an increase in inflation is less strong than the one implied by the standard linear Clarida et al.-type model. By contrast, there appears to be no evidence of any asymmetry on output. The estimate of $\gamma_{2}$ is insignificant and interest rates tend to react very little to the output gap in either the linear or asymmetric/non-linear model.

The results for the US reveal that the interest rate reaction function is convex in inflation. As explained in section 2.4, this type of convexity does not suffice to determine whether this is due to the presence of a precautionary demand for expansions on the part of the Fed, or to a precautionary demand for relatively low inflation rates (4\% or below). Given that there is no significant asymmetry in the output gap term it is not possible to discriminate between the two views. As a matter of fact the linearity in the output gap term in conjnunction with the convexity in inflation is also consistent with the view that precautionary demands for both inflation and the output gap are present, but that they offset each other as far as the the effect of the output gap on the interest rate is concerned. 
In the case of the UK, however, the interest rate reaction function is convex in both inflation and the output gap (both $\beta_{2}$ and $\gamma_{2}$ are significantly different from zero). The convexity in the output gap implies that monetary authorities in the the UK raised interest rates more aggressively during expansions than they reduced them during recessions. Given the theoretical framework in section 2 this finding suggests that the precautionary demand for low inflation dominated the behavior of policymakers in the UK. As we shall see below, this is true also for the latter part of the sample. Despite the persistence of inflation and the existence of different institutional regimes in the UK since 1979, these findings suggest that the majority of the period (1979-97) involved the political authorities in struggling to build up an antiinflationary reputation in spite of the fact that monetary policy had not been delegated to an independent central bank.

\section{Estimates for a latter Sub-Sample}

We examine next whether our results vary when we delete the first half of the eighties from the sample. There is considerable evidence from empirical work on linear interest rate reaction functions, that $\mathrm{CB}$ behavior has varied over time (Muscatelli et al, (1999), Muscatelli and Trecroci (2000)). Interestingly we find that, once we look at sub-sample estimates, an asymmetry on output appears in the US.

Estimates of the HTSTR model for the sub-sample 1985-1999 are reported in Table 4. All the non-linear output and inflation terms are now significant. In the case of Japan and the UK the restrictions $\widehat{\beta}_{1}=\widehat{\beta}_{2}$ and $\widehat{\gamma}_{1}=\widehat{\gamma}_{2}$ are now accepted by the data. This is not the case for the US, where instead we are able to impose $\widehat{\beta}_{1}=\widehat{\beta}_{2}$ and $\widehat{\gamma}_{1}=-\widehat{\gamma}_{2}$. 
Table 4: Sub-Sample GMM Estimates of Smooth-Transition non-Linear Reaction Functions

\begin{tabular}{|c|c|c|c|c|c|c|c|}
\hline \multirow[t]{2}{*}{$\overline{\text { Country }}$} & \multicolumn{5}{|c|}{ Short-Run Coefficients } & \multirow[t]{2}{*}{ Statistics } & \multirow{2}{*}{$\begin{array}{l}\text { Sample } \\
\text { Period }\end{array}$} \\
\hline & $\widehat{\widetilde{\alpha}}$ & $\widehat{\beta}_{1}$ & $\widehat{\beta}_{2}$ & $\widehat{\gamma}_{1}$ & $\widehat{\gamma}_{2}$ & & \\
\hline$\overline{\mathrm{USA}}$ & $\begin{array}{l}0.68 \\
(0.17)\end{array}$ & $\begin{array}{l}0.09 \\
(0.04)\end{array}$ & $\begin{array}{l}0.09 \\
(0.04)\end{array}$ & $\begin{array}{l}0.13 \\
(0.03)\end{array}$ & $\begin{array}{l}-0.13 \\
(0.03)\end{array}$ & $\begin{array}{l}\sigma=0.38 \\
J(10)= \\
2.98\end{array}$ & $\begin{array}{l}\text { 1985:1- } \\
\text { 1999:4 }\end{array}$ \\
\hline Japan & $\begin{array}{l}0.01 \\
(0.06)\end{array}$ & $\begin{array}{l}0.20 \\
(0.05)\end{array}$ & $\begin{array}{l}0.20 \\
(0.05)\end{array}$ & $\begin{array}{l}0.16 \\
(0.05)\end{array}$ & $\begin{array}{l}0.16 \\
(0.05)\end{array}$ & $\begin{array}{l}\sigma=0.39, \\
J(10)= \\
1.43\end{array}$ & $\begin{array}{l}1985: 1- \\
2000: 1\end{array}$ \\
\hline UK & $\begin{array}{l}1.07 \\
(0.48)\end{array}$ & $\begin{array}{l}0.15 \\
(0.07)\end{array}$ & $\begin{array}{l}0.15 \\
(0.07)\end{array}$ & $\begin{array}{l}0.10 \\
(0.04)\end{array}$ & $\begin{array}{l}0.10 \\
(0.04)\end{array}$ & $\begin{array}{l}\sigma=0.83, \\
J(10)= \\
8.64\end{array}$ & $\begin{array}{l}1985: 1- \\
1999: 3\end{array}$ \\
\hline
\end{tabular}

\begin{tabular}{||l||l|l|l|l|l|l||}
\hline \hline Country & \multicolumn{2}{|l||}{ Long-Run Coefficients } \\
\hline \hline & $\widehat{\widetilde{\alpha}} /(1-\widehat{\rho})$ & $\widehat{\beta}_{1} /(1-\widehat{\rho})$ & $\widehat{\beta}_{2} /(1-\widehat{\rho})$ & $\widehat{\gamma}_{1} /(1-\widehat{\rho})$ & $\widehat{\gamma}_{2} /(1-\widehat{\rho})$ & $\widehat{\rho}$ \\
\hline USA & 5.04 & 0.69 & 0.69 & 0.94 & -0.94 & 0.86 \\
& $(0.52)$ & $(0.27)$ & $(0.27)$ & $(0.23)$ & $(0.23)$ & $(0.03)$ \\
\hline Japan & 0.14 & 1.91 & 1.91 & 1.53 & 1.53 & 0.90 \\
& $(0.57)$ & $(0.38)$ & $(0.38)$ & $(0.58)$ & $(0.58)$ & $(0.04)$ \\
\hline UK & 4.74 & 0.66 & 0.66 & 0.44 & 0.44 & 0.78 \\
& $(0.56)$ & $(0.12)$ & $(0.12)$ & $(0.19)$ & $(0.19)$ & $(0.09)$ \\
\hline \hline
\end{tabular}

Notes: Numbers in parenthesis indicate standard errors (using a consistent covariance matrix for heteroscedasticity and serial correlation); $\sigma$ indicates the standard error of the estimate; J(n) is Hansen's test of the model's overidentifying restrictions, which is distributed as a $\chi^{2}(n)$ variate under the null hypothesis of valid overidentifying restrictions. The stars that are attached in some cases to the short run coefficients mean that those coefficients are significant at the 0.05 level of significance. 


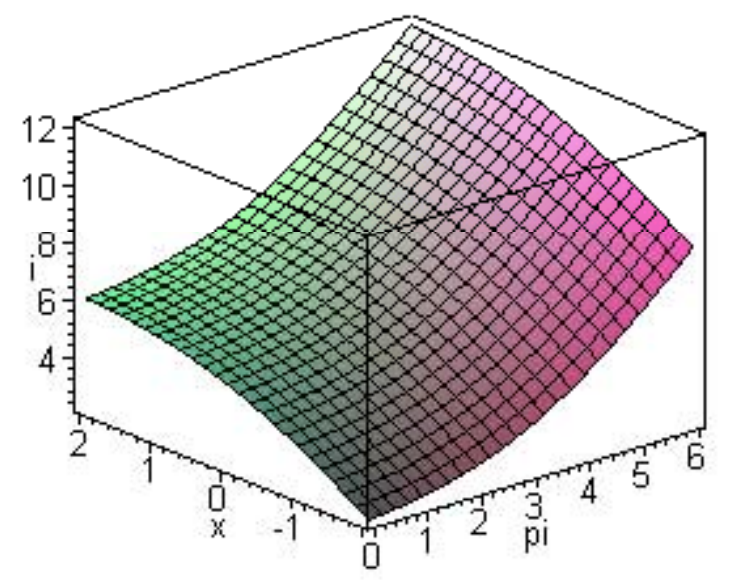

Figure 2: Nonlinear Reaction Functions: USA 1985-2000

Figure 2 plots the resulting long run non linear reaction function for the US. Although less prominent than in Figure 1, the convexity in inflation is still present. But the main novel feature of Figure 2 is the emergence of an output asymmetry, along the lines described in Section 2.5. The estimate of $\gamma_{2}$ is now negative and significant implying that the reaction function is a concave function of the expected output gap. To be precise, positive values of the output gap no longer lead to marked interest rate increases, whilst negative values lead to substantial cuts. In terms of our theoretical model (see equation (14)) this concave shape is consistent with the view that, after having brought inflation under control, the US Fed developed a precautionary demand for expansions. ${ }^{26}$ It seems that, following the credibility-building

${ }^{26}$ Differentiating equation $(20)$ with respect to $x_{\mathrm{t}, 1}$

$$
\frac{\partial^{2} i_{\mathrm{t}}}{\partial x_{\mathrm{t}, 1}^{2}}=\gamma_{2}\left[2 \psi F_{\mathrm{x}}^{0}\left(x_{\mathrm{t}, 1}\right)+x_{\mathrm{t}, 1} \psi^{2} F_{\mathrm{x}}^{\infty}\left(x_{\mathrm{t}, 1}\right)\right]
$$

where $F_{\mathrm{X}}\left(x_{\mathrm{t}, 1}\right) \equiv \tanh (\psi x)$. Simulations reveal that, for $\psi=0.25$ (which is the value of this parameter that is chosen by the grid search), the expression in brackets is positive for almost all the values of the output gap in our sample. Hence the reaction function is 
period of the early 1980s, the Fed became relatively more sensitive to recessions.

To examine whether this is a common feature across countries, we plot similar graphs for Japan and the UK in Figures 3 and 4 respectively. In the case of Japan the post-1985 period has brought with it lower interest rates, and a more salient asymmetry on inflation. The estimate of $\beta_{2}$ is now significant supporting the existence of some asymmetry in objectives. The fact that the reaction function is now significantly convex in the output gap ( $\gamma_{2}$ is positive and significant) supports the view that the dominant asymmetry in Japanese monetary policy, in the post 1985 period, is the precautionary demand for low inflation.

Unlike the US, the period since 1985 in the UK has been dominated by further reputation building (and since 1992 the adoption of inflation targeting, leading to CB independence in 1997). As is apparent from the short run coefficients in Table 4 the reaction of the interest rate to the output gap has a convex shape which is consistent (see equation (14)) with the existence of a dominant precautionary demand for low inflation.

Unfortunately it is not possible to establish, given the few data points at our disposal, whether UK behavior has changed since 1997. Estimating the model from 1992 as opposed to 1985 yields very similar results, with an interest rate reaction to the output gap which is convex. This re-enforces the view that during periods of reputation building (or disinflation), the precautionary demand for expansions becomes relatively less important, whilst once inflation has been under control for some time (the US since the mid-1980s), the precautionary demand for expansions dominates the precautionary demand for low inflation.

These findings lend support to the notion that policymakers try harder to avoid the retrospective policy mistakes which were most in evidence during the immediately preceding periods. Monetary policymakers seem to change their behavior over time in response to changing prevailing circumstances. They are likely to place greater weight on the most imminent risk of loss. At times of reputation building (like the UK in the nineties and the US in the early 1980s) inflation seems to be the number one priority, and output loss becomes relatively less important. Conversely during periods that are not characterized by credibility-building and disinflation (e.g. the USA in the post-1985 period), asymmetric preferences with respect to the output gap

concave in the output gap if and only if $\gamma_{2}$ is negative, as is the case in the US after 1985 . 


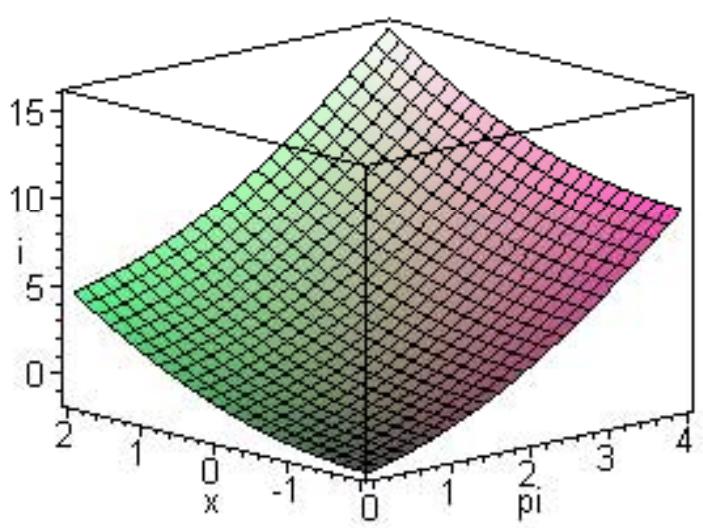

Figure 3: Nonlinear Reaction Function for Japan 1985-2000

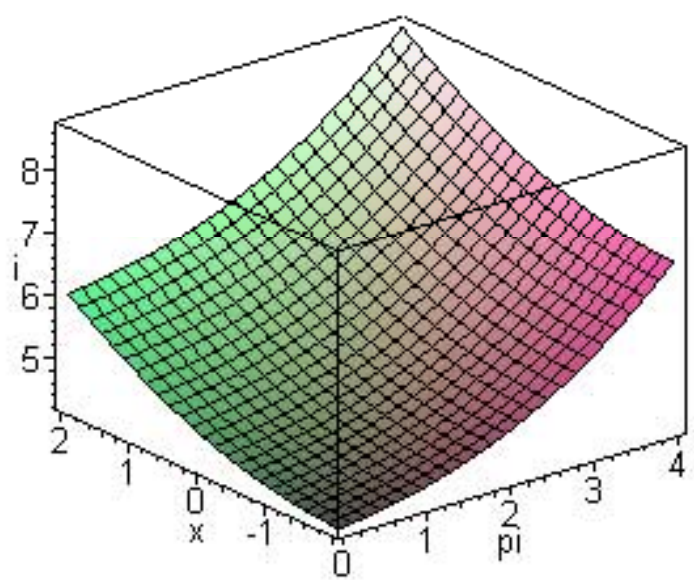

Figure 4: Nonlinear Reaction Function for UK, 1985-2000 
re-emerge, creating the potential for an inflation bias. ${ }^{27}$

\section{Conclusions}

At the theoretical level this paper shows how asymmetries in the monetary authority's objective function translate into non-linearities in interest rate reaction functions when the structure of the economy is characterized by a New - Keynesian transmission mechanism. At the empirical level the paper shows that there is empirical support for such non-linearities and asymmetries. This is done by estimating interest rate reaction functions, which allow for non linearities, for a number of G7 economies (the USA, Japan, Germany, and the UK). For all countries except Germany, there is some evidence of asymmetric behavior.

Of course, parameters of interest rate reaction functions are convolutions of preference parameters and of structural parameters of the economy. The theoretical framework implies that the existence of precautionary demands for both expansions and low inflation lead to reaction functions that are convex in expected inflation. When the precautionary demand for expansions dominates the conduct of monetary policy the reaction function is concave in the expected output gap. When the precautionary demand for low inflation dominates, the reaction function is convex in the expected output gap. Thus the nature of non linearity with respect to the expected output gap is informative about the dominant type of asymmetry in objectives. ${ }^{28}$

\footnotetext{
${ }^{27}$ As shown in the theory section larger losses from negative, than from positive, output gaps are consistent with the existence of a precautionary demand for expansions on the part of monetary authorities. Cukierman (2000) and Ruge-Murcia (2001) show, for a Lucas type supply function, that the existence of such a demand creates an inflation bias even if policymakers target the natural level of output on average. Section 5 in Cukierman (2002) shows that a similar result carries over to economies characterized by New - Keynesian transmission mechanisms as well.

${ }^{28} \mathrm{An}$ alternative general explanation for the non linear reaction functions detected in this paper is that they are due to non-linearities in economic structure, like a non-linear Phillips curve, rather than to asymmetric objectives. Akerlof, Dickens and Perry (2000) have recently proposed a framework that leads to non-linearities in economic struture. Discrimination between non-linear reaction functions due to asymmetric objectives from those that are due to non linearities in economic structure is an important topic for future research and is outside the scope of this paper.

However, even at this stage we can see that the theoretical implications of 'non linear Phillips relations' are going to be sensitive to the type of structural non linearity and may
} 
Using estimates for both the full sample period (1980 - 2000) and a latter sub - period (1985 - 2000), we find that the output asymmetries in the interest rate reaction function vary between countries and even within countries between different periods. For instance, it appears that where credibilitybuilding and disinflation has already been achieved (e.g. the USA after 1985), the monetary authorities develop a greater precautionary demand for output expansions than for low inflation. Conversely, where credibility-building is still a concern for the authorities (e.g. the UK over the eighties and part of the nineties), managing the business cycle for the monetary authorities is dominated by concerns to keep inflation expectations low.

The variation over time in the behavior of monetary authorities is sometimes attributed to institutional change. But as shifts in the behavior of the monetary authorities can also be detected in countries like the USA where the institutional structure has remained relatively stable, one could interpret shifts in behavior to the notion of 'framing', i.e. that the monetary authorities will attach greater weight to the most immediate prospect of loss. In particular, the empirical findings are consistent with the view that monetary authorities develop a stronger aversion to the losses that were mostly in evidence during the preceding several years.

A key conclusion which also emerges from the presence of asymmetries, and the precautionary demand for expansions (see Cukierman, 2002), is that a new source of inflationary bias can emerge. Unlike the traditional KydlandPrescott-Barro-Gordon inflation bias, the monetary authorities end up generating an inflation bias not because they are targeting a level of output which is too high, but because they are perceived by the private sector to react less aggressively to output expansions than to output contractions. Hence this precautionary demand for expansions may generate a resurgence in inflation expectations. It could well be that the 'death of inflation' has been somewhat exaggerated in the literature on inflation targets.

not explain the empirical findings in this paper. For example, if inflation in equation (2) is convex in the actual output gap (and therefore, via equation (1) also in the expected output gap), we would expect the interest rate reaction to be convex in the expected output gap under quadratic objectives. This is in clear contradiction to our finding that the interest rate is a concave function of the expected output gap in the post 1985 period in the US. 


\section{References}

Akerlof G. A., W. T. Dickens and G. L. Perry (2000) "Near Rational Wage and Price Setting and the Optimal Rates of Inflation and of Unemployment", Manuscript, May.

Bacon D.W. and Watts, D.G. (1971) "Estimating the Transition between Two Intersecting Straight Lines", Biometrika, 58, 525-34.

Barro, R.J. and Gordon, D.B. (1983) "A Positive Theory of Monetary Policy in a Natural Rate Model", Journal of Political Economy, 91, 589610.

Batini, N. and Haldane, A. (1999) "Forward-Looking Rules for Monetary Policy", in J.B. Taylor (ed.) Monetary policy rules. Chicago and London: University of Chicago Press.

Blinder, A.S. (1998) Central Banking in Theory and Practice, Cambridge MA: MIT Press.

Buiter, W. (1999) "Alice in Euroland", Journal of Common Market Studies, 37, no.2, June, 181-209.

Calvo, G. (1983) "Staggered Prices in a Utility-Maximizing Framework", Journal of Monetary Economics, 12, No.3, 383-98.

Clarida, R., Galí, J. and M. Gertler (1998) "Monetary Policy Rules in Practice: Some International Evidence", European Economic Review, 42, no. 6, pp. 1033-1067.

Clarida, R., Galí, J. and M. Gertler (1999). "The Science of Monetary Policy: a New Keynesian Perspective", Journal of Economic Literature, 37, December, 1661-1707.

Clarida, R., Galí, J. and M. Gertler (2000) "Monetary Policy Rules and Macroeconomic Stability: Evidence and Some Theory", Quarterly Journal of Economics, 113, 147-180, February.

Cukierman A. (1990). "Why Does the Fed Smooth Interest Rates?" in Monetary Policy on the Fed's 75 Anniversary - Proceedings of the 14th Annual Economic Policy Conference of the Federal Reserve Bank of St. Louis, M. Belongia (ed.), Kluwer Academic Publishers, 111-147.

Cukierman, A. (1992) Central Bank Strategy, Credibility and Independence: Theory and Evidence, Cambridge MA: MIT Press.

Cukierman, A. (2000) "The Inflation Bias Result Revisited", Manuscript Tel-Aviv University, April.

Available on the Internet at: http://www.tau.ac.il/ alexcuk/pdf/infbias1.pdf 
Cukierman A. (2001) "Accountability, Credibility, Transparency and Stabilization Policy in the Eurosystem ", in: Charles Wyplosz (ed.), The Impact of EMU on Europe and the Developing Countries, Oxford University Press, 40-75.

Cukierman, A. (2002) 'Are Contemporary Central Banks Transparent about Economic Models and Objectives and What Difference Does it Make? Forthcoming : Federal Reserve Bank of St. Louis Review , July/August 2002.

Available on the Internet at: http://www.tau.ac.il/ alexcuk/pdf/transparency.pdf

Dolado, J.J., Ramon, M-D. and M. Naveira (2000) "Asymmetries in Monetary Policy: Evidence for Four Central Banks", CEPR Discussion Paper n. 2441.

Galí, J., Gertler, and Lopez-Salido, J.D. (2001). "European Inflation Dynamics", European Economic Review, 45, 1237-70.

Geraat P. M. (1999) "Inflation and its Variation: An Alternative Explanation", CIDER Working Paper C99-105, Department of Economics, University of California, Berkeley, July.

Gerlach, S. (2000) "Asymmetric Policy reactions and Inflation", Manuscript, BIS, April.

Goodhart, C.A.E. (1999) "Central Bankers and Uncertainty", Bank of England Quarterly Bulletin, 102-21, February.

Granger, C.W.J. and Terasvirta, T. (1993). Modelling Non-Linear Economic Relationships,.Oxford: Oxford University Press.

Hansen, L.P. (1982) "Large Sample Properties of Generalized Method of Moments Estimators", Econometrica, 50, 1029-54.

Issing, O. (1999) "The Eurosystem: Transparent and Accountable or 'Willem in Euroland"' Journal of Common Market Studies, 37, No.3, September, 503-19.

Jordan T. J. (2001) Inflation Bias, Output Stabilization, and Central Bank Independence, Verlag Paul Haupt, Bern, Stuttgart, Wien.

Kahneman, D., \& Tversky, A. (1979) "Prospect Theory: An Analysis of Decision Under Risk", Econometrica 47, 263-291.

Kahneman, D., \& Tversky, A. (1982) "The Psychology of Preferences", Scientific American, 246, 160-173.

Kahneman, D., \& Tversky, A. (1984) "Choice, Values, and Frames", American Psychologist, 39, 341-350.

Kimball M. S. (1990), "Precautionary Saving in the Small and in the Large", Econometrica, 58, January, 53-73. 
Kydland F.E. and Prescott, E.C. (1977) "Rules Rather than Discretion: the Inconsistency of Optimal Plans" Journal of Political Economy, 85, 473-92.

McCallum, B. (1997) "Crucial Issues Concerning Central Bank Independence", Journal of Monetary Economics, 39, 99-112.

Muscatelli, V.A., Tirelli, P. and C. Trecroci (1999) "Does Institutional Change Really Matter? Inflation Targets, Central Bank Reform and Interest Rate Policy in the OECD Countries", University of Glasgow Discussion Paper, n.9920, forthcoming in The Manchester School, Special Issue on Inflation Targeting.

Muscatelli, V.A. and Trecroci, C. (2000), "Central Bank Goals, Institutional Change and Monetary Policy: Evidence from the US and UK", forthcoming in L. Mahadeva, P. Sinclair and G. Sterne (eds.) Monetary Transmissions in Diverse Economies, Cambridge and London: Cambridge University Press and Bank of England.

Nobay, R. and Peel, D. (1998) "Optimal Monetary Policy in a Model of Asymmetric Central Bank Preferences", Manuscript, London School of Economics.

Rudebusch, G.D., and L.E.O. Svensson (1999) "Policy rules for Inflation Targeting", in J.B. Taylor (ed.) Monetary Policy Rules. Chicago and London: University of Chicago Press.

Ruge-Murcia, F.J. (2000) "Deflation and Optimal Monetary Policy",.Manuscript, University of Montreal, October.

Ruge-Murcia F. J. (2001) "The Inflation Bias When the Central Bank Targets the Natural Rate of Unemployment", Manuscript, University of Montreal, September, Forthcoming: European Economic Review.

Seber, G.A.F. and Wild, C.J. (1989).Non-Linear Regression. New York: Wiley.

Svensson, L.E.O. (1997) "Optimal Inflation Targets, Conservative Central Banks and Linear Inflation Contracts. American Economic Review, 87, 98-114.

Svensson, L.E.O. (2000). "Open-Economy Inflation Targeting", Journal of International Economics, 50, 155-183.

Vickers, J. (1998) "Inflation Targeting in Practice: the UK Experience", Bank of England Quarterly Bulletin, 38, No.4, 368-75. 


\section{Data Appendix}

\begin{tabular}{|l|l|l|l|l|}
\hline Time Series & GDP for $x$ & $\begin{array}{l}\text { (Potential } \\
\text { GDP) for } x\end{array}$ & $\pi$ & $i$ \\
\hline USA & BEA & BEA & $\begin{array}{l}\text { Retail In- } \\
\text { Price In } \\
\text { dex (OECD) }\end{array}$ & $\begin{array}{l}\text { Federal Funds } \\
\text { Rate (IFS) }\end{array}$ \\
\hline Germany & OECD & OECD & $\begin{array}{l}\text { Retail In- } \\
\text { Price } \\
\text { dex (OECD) }\end{array}$ & $\begin{array}{l}\text { Call Money } \\
\text { Rate (IFS) }\end{array}$ \\
\hline Japan & OECD & OECD & $\begin{array}{l}\text { Retail } \\
\text { Price In- } \\
\text { dex (OECD) }\end{array}$ & $\begin{array}{l}\text { Call Mate (IFS) } \\
\text { Rat }\end{array}$ \\
\hline UK & OECD & OECD & $\begin{array}{l}\text { CPIX up } \\
\text { to 1987Q1 } \\
\text { (OECD), } \\
\text { RPIX there- } \\
\text { after (ONS) }\end{array}$ & $\begin{array}{l}\text { London } \\
\text { Clear- } \\
\text { Overnight Banks } \\
\text { Rate (IFS) }\end{array}$ \\
\hline
\end{tabular}

Note: $x$ is defined as the output gap as a percentage of potential output; potential output data is 6-monthly and interpolated to obtain quarterly data. 


\section{CESifo Working Paper Series}

695 Hans Gersbach, Financial Intermediation and the Creation of Macroeconomic Risks, April 2002

696 James M. Malcomson, James W. Maw, and Barry McCormick, General Training by Firms, Apprentice Contracts, and Public Policy, April 2002

697 Simon Gächter and Arno Riedl, Moral Property Rights in Bargaining, April 2002

698 Kai A. Konrad, Investment in the Absence of Property Rights: The Role of Incumbency Advantages, April 2002

699 Campbell Leith and Jim Malley, Estimated General Equilibrium Models for the Evaluation of Monetary Policy in the US and Europe, April 2002

700 Yin-Wong Cheung and Jude Yuen, Effects of U.S. Inflation on Hong Kong and Singapore, April 2002

701 Henry Tulkens, On Cooperation in Musgravian Models of Externalities within a Federation, April 2002

702 Ralph Chami and Gregory D. Hess, For Better or For Worse? State-Level Marital Formation and Risk Sharing, April 2002

703 Fredrik Andersson and Kai A. Konrad, Human Capital Investment and Globalization in Extortionary States, April 2002

704 Antonis Adam and Thomas Moutos, The Political Economy of EU Enlargement: Or, Why Japan is not a Candidate Country?, April 2002

705 Daniel Gros and Carsten Hefeker, Common Monetary Policy with Asymmetric Shocks, April 2002

706 Dirk Kiesewetter and Rainer Niemann, Neutral and Equitable Taxation of Pensions as Capital Income, April 2002

707 Robert S. Chirinko, Corporate Taxation, Capital Formation, and the Substitution Elasticity between Labor and Capital, April 2002

708 Frode Meland and Gaute Torsvik, Structural Adjustment and Endogenous Worker Recall Probabilities, April 2002

709 Rainer Niemann and Caren Sureth, Taxation under Uncertainty - Problems of Dynamic Programming and Contingent Claims Analysis in Real Option Theory, April 2002

710 Thomas Moutos and William Scarth, Technical Change and Unemployment: Policy Responses and Distributional Considerations, April 2002 
711 Günther Rehme, (Re-)Distribution of Personal Incomes, Education and Economic Performance Across Countries, April 2002

712 Thorvaldur Gylfason and Gylfi Zoega, Inequality and Economic Growth: Do Natural Resources Matter?, April 2002

713 Wolfgang Leininger, Contests over Public Goods: Evolutionary Stability and the FreeRider Problem, April 2002

714 Ernst Fehr and Armin Falk, Psychological Foundations of Incentives, April 2002

715 Giorgio Brunello, Maria Laura Parisi, and Daniela Sonedda, Labor Taxes and Wages: Evidence from Italy, May 2002

716 Marta Aloi and Huw Dixon, Entry Dynamics, Capacity Utilisation and Productivity in a Dynamic Open Economy, May 2002

717 Paolo M. Panteghini, Asymmetric Taxation under Incremental and Sequential Investment, May 2002

718 Ben J. Heijdra, Christian Keuschnigg, and Wilhelm Kohler, Eastern Enlargement of the EU: Jobs, Investment and Welfare in Present Member Countries, May 2002

719 Tapio Palokangas, The Political Economy of Collective Bargaining, May 2002

720 Gilles Saint-Paul, Some Evolutionary Foundations for Price Level Rigidity, May 2002

721 Giorgio Brunello and Daniela Sonedda, Labor Tax Progressivity, Wage Determination, and the Relative Wage Effect, May 2002

722 Eric van Damme, The Dutch UMTS-Auction, May 2002

723 Paolo M. Panteghini, Endogenous Timing and the Taxation of Discrete Investment Choices, May 2002

724 Achim Wambach, Collusion in Beauty Contests, May 2002

725 Dominique Demougin and Claude Fluet, Preponderance of Evidence, May 2002

726 Gilles Saint-Paul, Growth Effects of Non Proprietary Innovation, May 2002

727 Subir Bose, Gerhard O. Orosel, and Lise Vesterlund, Optimal Pricing and Endogenous Herding, May 2002

728 Erik Leertouwer and Jakob de Haan, How to Use Indicators for 'Corporatism' in Empirical Applications, May 2002

729 Matthias Wrede, Small States, Large Unitary States and Federations, May 2002 
730 Christian Schultz, Transparency and Tacit Collusion in a Differentiated Market, May 2002

731 Volker Grossmann, Income Inequality, Voting Over the Size of Public Consumption, and Growth, May 2002

$732 \mathrm{Yu}-\mathrm{Fu}$ Chen and Michael Funke, Working Time and Employment under Uncertainty, May 2002

733 Kjell Erik Lommerud, Odd Rune Straume, and Lars Sørgard, Downstream Merger with Oligopolistic Input Suppliers, May 2002

734 Saku Aura, Does the Balance of Power Within a Family Matter? The Case of the Retirement Equity Act, May 2002

735 Sandro Brusco and Fausto Panunzi, Reallocation of Corporate Resources and Managerial Incentives in Internal Capital Markets, May 2002

736 Stefan Napel and Mika Widgrén, Strategic Power Revisited, May 2002

737 Martin W. Cripps, Godfrey Keller, and Sven Rady, Strategic Experimentation: The Case of Poisson Bandits, May 2002

738 Pierre André Chiappori and Bernard Salanié, Testing Contract Theory: A Survey of Some Recent Work, June 2002

739 Robert J. Gary-Bobo and Sophie Larribeau, A Structural Econometric Model of Price Discrimination in the Mortgage Lending Industry, June 2002

740 Laurent Linnemer, When Backward Integration by a Dominant Firm Improves Welfare, June 2002

741 Gebhard Kirchgässner and Friedrich Schneider, On the Political Economy of Environmental Policy, June 2002

742 Christian Keuschnigg and Soren Bo Nielsen, Start-ups, Venture Capitalits, and the Capital Gains Tax, June 2002

743 Robert Fenge, Silke Uebelmesser, and Martin Werding, Second-best Properties of Implicit Social Security Taxes: Theory and Evidence, June 2002

744 Wendell Fleming and Jerome Stein, Stochastic Optimal Control, International Finance and Debt, June 2002

745 Gene M. Grossman, The Distribution of Talent and the Pattern and Consequences of International Trade, June 2002

746 Oleksiy Ivaschenko, Growth and Inequality: Evidence from Transitional Economies, June 2002

747 Burkhard Heer, Should Unemployment Benefits be Related to Previous Earnings?, July 2002 
748 Bas van Aarle, Giovanni Di Bartolomeo, Jacob Engwerda, and Joseph Plasmans, Staying Together or Breaking Apart: Policy-makers' Endogenous Coalitions Formation in the European Economic and Monetary Union, July 2002

749 Hans Gersbach, Democratic Mechanisms: Double Majority Rules and Flexible Agenda Costs, July 2002

750 Bruno S. Frey and Stephan Meier, Pro-Social Behavior, Reciprocity or Both?, July 2002

751 Jonas Agell and Helge Bennmarker, Wage Policy and Endogenous Wage Rigidity: A Representative View From the Inside, July 2002

752 Edward Castronova, On Virtual Economies, July 2002

753 Rebecca M. Blank, U.S. Welfare Reform: What's Relevant for Europe?, July 2002

754 Ruslan Lukach and Joseph Plasmans, Measuring Knowledge Spillovers Using Patent Citations: Evidence from the Belgian Firm's Data, July 2002

755 Aaron Tornell and Frank Westermann, Boom-Bust Cycles in Middle Income Countries: Facts and Explanation, July 2002

756 Jan K. Brueckner, Internalization of Airport Congestion: A Network Analysis, July 2002

757 Lawrence M. Kahn, The Impact of Wage-Setting Institutions on the Incidence of Public Employment in the OECD: 1960-98, July 2002

758 Sijbren Cnossen, Tax Policy in the European Union, August 2002

759 Chandima Mendis, External Shocks and Banking Crises in Developing Countries: Does the Exchange Rate Regime Matter?, August 2002

760 Bruno S. Frey and Lars P. Feld, Deterrence and Morale in Taxation: An Empirical Analysis, August 2002

761 Lars Calmfors and Åsa Johansson, Nominal Wage Flexibility, Wage Indexation and Monetary Union, August 2002

762 Alexander R. W. Robson and Stergios Skaperdas, Costly Enforcement of Property Rights and the Coase Theorem, August 2002

763 Horst Raff, Preferential Trade Agreements and Tax Competition for Foreign Direct Investment, August 2002

764 Alex Cukierman and V. Anton Muscatelli, Do Central Banks have Precautionary Demands for Expansions and for Price Stability? - Theory and Evidence, August 2002 